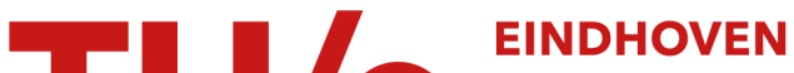 \\ UNIVERSITY OF \\ TECHNOLOGY
}

\section{Oxygen reduction at polypyrrole electrodes - II. Experimental results}

Citation for published version (APA):

Jakobs, R. C. M., Janssen, L. J. J., \& Barendrecht, E. (1985). Oxygen reduction at polypyrrole electrodes - II. Experimental results. Electrochimica Acta, 30(11), 1433-1439. https://doi.org/10.1016/0013-4686(85)80003-7

DOI:

10.1016/0013-4686(85)80003-7

Document status and date:

Published: 01/01/1985

\section{Document Version:}

Publisher's PDF, also known as Version of Record (includes final page, issue and volume numbers)

\section{Please check the document version of this publication:}

- A submitted manuscript is the version of the article upon submission and before peer-review. There can be important differences between the submitted version and the official published version of record. People interested in the research are advised to contact the author for the final version of the publication, or visit the $\mathrm{DOI}$ to the publisher's website.

- The final author version and the galley proof are versions of the publication after peer review.

- The final published version features the final layout of the paper including the volume, issue and page numbers.

Link to publication

\section{General rights}

Copyright and moral rights for the publications made accessible in the public portal are retained by the authors and/or other copyright owners and it is a condition of accessing publications that users recognise and abide by the legal requirements associated with these rights.

- Users may download and print one copy of any publication from the public portal for the purpose of private study or research.

- You may not further distribute the material or use it for any profit-making activity or commercial gain

- You may freely distribute the URL identifying the publication in the public portal.

If the publication is distributed under the terms of Article $25 \mathrm{fa}$ of the Dutch Copyright Act, indicated by the "Taverne" license above, please follow below link for the End User Agreement:

www.tue.nl/taverne

Take down policy

If you believe that this document breaches copyright please contact us at:

openaccess@tue.nl

providing details and we will investigate your claim. 


\title{
OXYGEN REDUCTION AT POLYPYRROLE ELECTRODES-II. EXPERIMENTAL RESULTS
}

\author{
R. C. M. JAKobS, L. J. J. JANSSEN and E. BARENDRECHT
}

\begin{abstract}
Laboratory for Electrochemistry, Department of Chemistry, Eindhoven University of Technology,
\end{abstract} P.O. Box 513, 5600 MB Eindhoven, The Netherlands

(Received 4 December 1984)

\begin{abstract}
The cathodic reduction of molecular oxygen at a polypyrrole electrode in $0.5 \mathrm{M} \mathrm{H}_{2} \mathrm{SO}_{4}$ is studied using a rrde. It appears that the polymeric layer is permeable and that the reduction of oxygen mainly occurs at the interface metal/polypyrrole. Due to the presence of the polymer layer, eventually formed peroxide is not immediately removed by convection, but is forced to diffuse through the polymer, back to the bulk of the electrolyte. Because of the accompanying increase of the mean residence time of peroxide near the metal/polypyrrole interface, the selectivity of oxygen reduction to water at the polypyrrole electrode is more than at the uncovered metal. However, the maximum current density at the polypyrrole electrode is less than at the uncovered metal.

It is found, that for the so-called "oxidized polypyrrole electrode", the polymer film probably catalyses the decomposition of hydrogen peroxide to water and molecular oxygen and thus contributes to a more favourable selectivity of the electrode.
\end{abstract}

\section{NOMENCLATURE}

$A_{\mathrm{D}} \quad$ disc surface area $\mathrm{m}^{2}$

$c$ concentration $\mathbf{M}, \mathrm{mol} \mathrm{m}^{-3}$

D diffusion coefficient $m^{2} s^{-1}$

E potential V

$E_{\mathrm{D}}$ disc potential $\mathrm{V}$

$E_{\mathrm{R}}^{\mathrm{D}}$ ring potential V

F $\quad$ Faraday's constant $\mathrm{Cmol}^{-1}$

$f \quad$ (rotation) frequency $\mathrm{Hz}$

$I_{\mathrm{D}} \quad$ disc current $\mathrm{A}$

$I_{\mathrm{D}, \text { I limiting disc current } \mathrm{A}}$

$I_{\mathrm{R}}$ ring current $\mathbf{A}$

$I_{\mathrm{R}}^{0} \quad$ ring current at $E_{\mathrm{D}}=0.8 \mathrm{~V} \mathrm{~A}$

$I_{\mathbf{R}, l}$ limiting ring current $A$

$I_{\mathrm{R}, l}^{0} \quad$ limiting ring current at $E_{\mathrm{D}}=0.8 \mathrm{~V} \mathrm{~A}$

$k$ heterogeneous reaction rate constant $\mathrm{m} \mathrm{s}^{-1}$

$l$ thickness of the polymer film $m$

$N \quad$ collection efficiency

$n_{\mathrm{a}}$ number of electrons, involved in overall electrode reaction equation

$p\left(\mathrm{H}_{2} \mathrm{O}\right)$ water formation efficiency

$Q$ charge passed during film formation per unit geometrical surface area $\mathrm{Cm}^{-2}$

$\begin{array}{ll}T & \text { absolute temperature } K \\ v_{D} & \text { disc potential scan rate } \mathrm{Vs}_{\mathrm{s}}{ }^{-1}\end{array}$

$\delta \quad$ diffusion layer thickness $m$

$v \quad$ kinematic viscosity $\mathrm{m}^{2} \mathrm{~s}^{-1}$

\section{Superscripts}

ad adsorbed

f polymer film

s bulk

$\sigma \quad$ interphase metal/polypyrrole

\section{INTRODUCTION}

We have shown, that, for the cathodic reduction of molecular oxygen in $0.5 \mathrm{M} \mathrm{H}_{2} \mathrm{SO}_{4}$, the heterogeneous reaction rate constants can be determined when using a rrde $[1,2]$

In addition to the results which lead to the determination of these rate constants, the behaviour of the polypyrrole electrode with respect to the oxygen reduction is studied in a more general way[2]. The results of these additional investigations are presented in this paper.

\section{EXPERIMENTAL}

For the preparation of the polypyrrole films, the same cell, electronic equipment and setup was used as described earlier[3]. The formation electrolyte contained $0.1 \mathrm{M} \mathrm{LiClO} 4$ (Fluka), $0.144 \mathrm{M}$ pyrrole (Aldrich) in acetonitrile (Janssen Chimica). The acetonitrile contains 0.055 vol. \% water, which is determined by Karl Fischer titration.

Two types of rrde were used, viz. a Au disc/Au ring electrode assembly and a $\mathrm{Pt}$ disc/Pt ring electrode assembly, denoted respectively by $\mathrm{Au} / \mathrm{Au}$ and $\mathrm{Pt} / \mathrm{Pt}$. The collection efficiencies of the $\mathrm{Pt} / \mathrm{Pt}$ and the $\mathrm{Au} / \mathrm{Au}$ electrode assemblies are, respectively, 0.241 and 0.144 .

Each electrode assembly was polished with $0.05 \mu \mathrm{m}$ alumina before deposition of the polypyrrole film. When the Au/Au rrde was used, the Au ring of this rrde was platinized[4] to obtain a sufficient activity for peroxide detection. After this, the polypyrrole film was formed onto the disc, giving a $\mathrm{PP}(\mathrm{Au}) / \mathrm{Pt}(\mathrm{Au})$ electrode assembly (the notation is such, that the base material is given between parentheses). Additionally, a $\mathrm{PP}(\mathbf{P t}) / \mathrm{Pt}$ rrde was used, of which the ring was not platinized.

The polymer films were formed at $298 \mathrm{~K}, 100 \mathrm{kPa}$ and at a constant formation potential of $1.20 \mathrm{~V}$ vs sce. The ring electrode was not charged during the polymerization process. 
After formation of the polypyrrole film, the electrode was rinsed with ethanol during $30 \mathrm{~s}$, dried in ambient air for $30 \mathrm{~min}$ and transferred to the cell in which the oxygen reduction experiments were conducted.

The oxygen reduction cell was a thermostatted glass cell, connected to a bipotentiostat (Tacussel Bi-Pad). As reference electrode, a reversible hydrogen electrode $\left[p\left(\mathrm{H}_{2}\right)=100 \mathrm{kPa}\right]$ was used in the same solution as where the ring-disc measurements were carried out. The electrode was provided with a Luggin capillary of which the tip was positioned about $15 \mathrm{~mm}$ underneath the working electrode. All potentials are with respect to this teference electrode. The counter electrode was a platinum foil, separated from the rrde by a porous glass filter. The electrolyte was a $0.5 \mathrm{M} \mathrm{H}_{2} \mathrm{SO}_{4}$ solution in distilled water and all the gases were used at a partial pressure of $100 \mathrm{kPa}$.

During the ring-disc measurements, the disc potential was determined by triangular potential sweep with a potential scan speed $v_{\mathrm{D}}=0.05 \mathrm{Vs}^{-1}$, while the ring was kept at a constant peroxide detection potential, namely $E_{\mathrm{R}}=1.25 \mathrm{~V}$. The rotation frequency of the rrde was varied from 0 up to $81 \mathrm{~Hz}$. The ring and disc currents were plotted against the disc potential, using a dual-pen $x-y$ recorder.

In some cases, the $I_{\mathrm{D}}-E_{\mathrm{D}}$ curve for the potential sweep in anodic direction shows a maximum and the curve for the cathodic scan is a well-shaped wave. Hence, for all potential sweep curves, the disc and ring currents for decreasing disc potential (ie the cathodic scan) are used as disc and ring currents in the next. Moreover, a PP electrode which has been aged at a disc potential $E_{D} \leqslant 0.9 \mathrm{~V}$ is designated as a reduced electrode. A PP electrode for which $E_{\mathrm{D}}$ becomes more positive than $0.9 \mathrm{~V}$, is designated as an oxidized electrode.

\section{RESULTS}

\subsection{Reduced electrode}

The effect of a reduced PP film (formation charge $Q=0.6 \mathrm{kC} \mathrm{m}^{-2}$ ) on the cathodic oxygen reduction at a $\mathrm{Au} / \mathrm{Pt}(\mathrm{Au})$ rrde in $0.5 \mathrm{M} \mathrm{H}_{2} \mathrm{SO}_{4}$ is shown in Fig. 1 . The results were obtained after the electrode was aged at a constant disc potential of $0.20 \mathrm{~V}$.

Figure 1 shows that the oxygen reduction at the PPcovered disc starts at a more positive potential than at the uncovered $A u$ disc, and the shape of $E_{D}-I_{D}$ curves are clearly diffferent.

During oxygen reduction, peroxide is formed at both electrodes. From Fig. 1 it follows that the water formation efficiency $p\left(\mathrm{H}_{2} \mathrm{O}\right)[1]$ for the uncovered electrode is substantially less than that for the PP. covered electrode.

From a plot of $I_{\mathrm{D}} / I_{\mathrm{D}, i}[1]$ vs $E_{\mathrm{D}}$ it follows that for the uncovered $\mathrm{Au}$ electrode the condition of diffusion limitation is not reached in the potential range examined, For the PP electrode, a limiting current has been found at $0.1 \mathrm{~V}<E_{\mathrm{D}}<0.3 \mathrm{~V}$, with $\left(I_{\mathrm{D}} / I_{\mathrm{D}, l}\right)_{\max }$ $\simeq 0.4$, where $I_{\mathrm{D} .1}$ has been calculated with the Levich equation. It is likely that the polymer film affects the limiting current as determined by diffusion of dissolved oxygen through the polymer film.

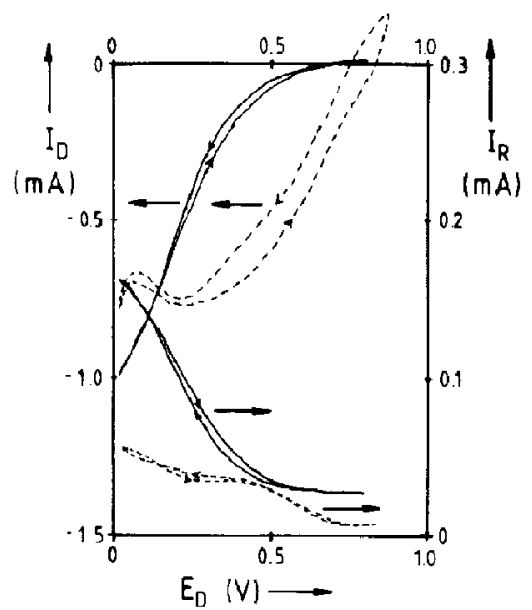

Fig. 1. $\mathrm{O}_{2}$ reduction at a reduced $\mathrm{Au} / \mathrm{Pt}(\mathrm{Au}) \mathrm{rrde}$ in $\mathrm{O}_{2}$ saturated $0.5 \mathrm{M} \mathrm{H}_{2} \mathrm{SO}_{4}$. Disc aged $1 \frac{1}{2} \mathrm{hr}$ at $E_{\mathrm{D}}=0.20 \mathrm{~V}$. $v_{\mathrm{D}}$ $=0.05 \mathrm{~V} \mathrm{~s}^{-1}, E_{\mathrm{R}}=1.25 \mathrm{~V}, f=25 \mathrm{~Hz}, T=298 \mathrm{~K}$. Uncovered disc.,$---- P P$-covered disc $\left(Q=0.6 \mathrm{kC} \mathrm{m}^{-2}\right)$.

For an uncovered Pt disc, of which the disc is aged for $90 \mathrm{hr}$, the reduction current at $E_{D}=0.20 \mathrm{~V}$ decreases from 1.98 to $0.06 \mathrm{~mA}$. At the same time $I_{\mathrm{R}}-I_{\mathrm{R}}^{0}[1]$ decreases during aging from 0.118 to $0.026 \mathrm{~mA}$. So, a decrease of the disc current by a factor 33 is accompanied with a decrease of the peroxide formation by a factor 4.5 . This means that, during the aging period, the selectivity for water formation has become significantly less. When the disc potential is subsequently scanned between 0.02 and $0.80 \mathrm{~V}$, the reduction current recovers to a value of about $-2 \mathrm{~mA}$.

For a reduced $\mathrm{Pt} / \mathrm{Pt}(\mathrm{Pt})$ electrode, aged for $1 \frac{1}{2} \mathrm{hr}$ and $90 \mathrm{hr}$, it has been found that, in both cases, the diffusion limited current with $\left(I_{\mathrm{D}} / I_{\mathrm{D}, 1}\right)_{\max } \simeq 1$ occurs at $0.1 \mathrm{~V}<E_{\mathrm{D}}<0.3 \mathrm{~V}$.

The results for a $\mathbf{P P}(\mathbf{P t}) / \mathbf{P t}$ electrode $(Q=0.6$ $\mathbf{k C ~ ~ m ^ { - 2 }}$ ) are presented in Fig. 2 for the first $7 \mathrm{hr}$ of the aging period. From this figure it can be deduced that the water formation efficiency during $\mathrm{O}_{2}$ reduction is almost constant during the first $7 \mathrm{hr}$ of the aging process; the increase of the background ring current $I_{\mathrm{R}}^{0}$ with increasing aging time indicates a build-up of peroxide in the bulk electrolyte. Figure 2 shows the occurrence of a hysteresis between the anodic and cathodic potential sweep, due to the redox behaviour of the polymer and the hysteresis decreases with increasing aging time. Moreover, the hysteresis was independent of the electrode's rotation frequency and the presence of dissolved oxygen. It was linearly dependent of the potential scan rate so, apparently, various electrochemical reactions occur in or at the pulymer film.

From Fig. 3, in which the water formation efficiency for the PP(Pt) electrode at $293 \mathrm{~K}$ is presented, it follows that, during the first $7 \mathrm{hr}$, the electrode porduces practically no peroxide over the total potential range. After $168 \mathrm{hr}$ of aging, however, $p\left(\mathrm{H}_{2} \mathrm{O}\right)$ has become less than 0.5 for $0.1 \mathrm{~V}<E_{\mathrm{D}}<0.3 \mathrm{~V}$. Additionally, it has been found that $\left(I_{\mathrm{D}} / I_{\mathrm{D}, d}\right)_{\mathrm{max}}$ decreases from 0.4 to 0.3 during $168 \mathrm{hr}$ of aging. 


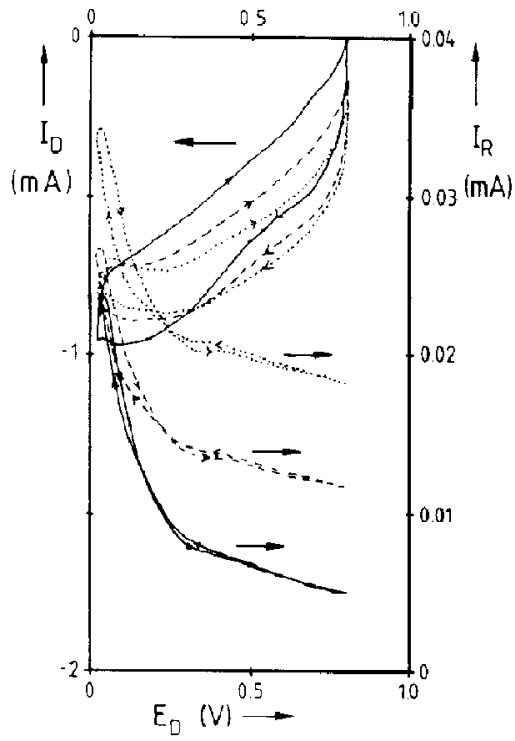

Fig. 2. $\mathrm{O}_{2}$ reduction at a reduced $\mathrm{PP}(\mathrm{Pt}) / \mathrm{Pt}$ rrde in $\mathbf{O}_{2}$ saturated $0.5 \mathrm{M} \mathrm{H}_{2} \mathrm{SO}_{4} . v_{\mathrm{D}}=0.05 \mathrm{~V} \mathrm{~s}^{-1}, \quad E_{\mathrm{R}}=1.25 \mathrm{~V}$, $f=25 \mathrm{~Hz}, \quad T=298 \mathrm{~K}, Q=0.6 \mathrm{kC} \mathrm{m}^{-2}$. Aging time at $E_{\mathrm{D}}=0.20 \mathrm{V:} 1 \mathrm{hr}(-), 3 \mathrm{hr}(---)$ and $7 \mathrm{hr}(\cdots)$.

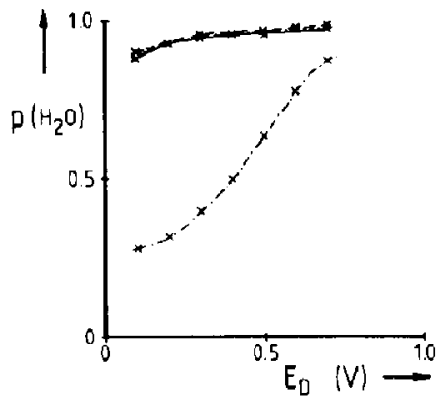

Fig. 3. Water formation efficiency during $\mathrm{O}_{2}$ reduction at a reduced $\mathrm{PP}(\mathrm{Pt}) / \mathrm{Pt}$ rrde in $\mathrm{O}_{2}$-saturated $0.5 \mathrm{M} \mathrm{H}_{2} \mathrm{SO}_{4} \cdot v_{\mathrm{D}}$ $=0.05 \mathrm{~V} \mathrm{~s}^{-1}, f=25 \mathrm{~Hz}, T=298 \mathrm{~K}, Q=0.6 \mathrm{kC} \mathrm{m}^{-2}$. Aging time at $E_{\mathrm{D}}=0.20 \mathrm{~V}: 1 \mathrm{hr}(-), 3 \mathrm{hr}(\cdots-), 7 \mathrm{hr}(\cdots)$ and $168 \mathrm{hr}(-\cdot \cdot \cdot)$

When the PP electrode is aged and measured at an elevated temperature, viz. $353 \mathrm{~K}$, the aging process takes place at an increased rate. The effect of the temperature on the water formation efficiency at a $\mathrm{PP}(\mathrm{Pt})$ electrode is presented in Fig. 4. The results show that $p\left(\mathrm{II}_{2} \mathrm{O}\right)$ increases with increasing tempcrature. A plot of $I_{\mathrm{D}} / I_{\mathrm{D}}$ vs the disc potential gives $\left(I_{\mathrm{D}} / I_{\mathrm{D}, i}\right)_{\max } \simeq 0.6$ for all temperatures.

In an experiment, a PP(Pt) electrode was aged for $67 \frac{1}{2} \mathrm{hr}$ at $E_{\mathrm{D}}=0.20 \mathrm{~V}$ in $\mathrm{O}_{2}$-saturated $0.5 \mathrm{M} \mathrm{H}_{2} \mathrm{SO}_{4}$. After the aging period, the electrolyte was deoxygenated, hydrogen peroxide was added, to a concentration of $1.08 \times 10^{-3} \mathrm{M}$ and a potential sweep curve was recorded. The result is given in Fig. 5. Now, a reduction

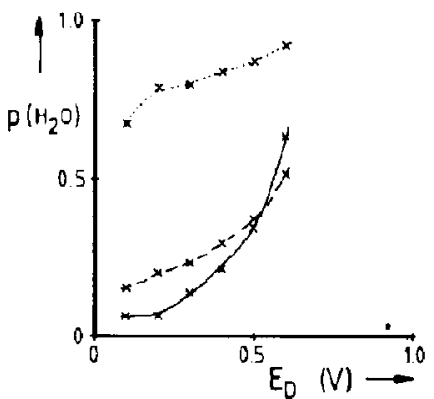

Fig. 4. Water formation efficiency during $\mathrm{O}_{2}$ reduction at a reduced $P P(P t)$ electrode in $\mathrm{O}_{2}$-saturated $0.5 \mathrm{M} \mathrm{H}_{2} \mathrm{SO}_{4}$ at various temperatures. Disc aged $72 \mathrm{hr}$ at $E_{\mathrm{D}}=0.20 \mathrm{~V}$ and $T$ $=293 \mathrm{~K} . v_{\mathrm{D}}=0.05 \mathrm{Vs}^{-1}, f=25 \mathrm{~Hz}, Q=0.6 \mathrm{kC} \mathrm{m}^{-2}$. Temperatures: $308 \mathrm{~K}(-), 323 \mathrm{~K}(-\cdots)$ and $338 \mathrm{~K}(\cdots)$.

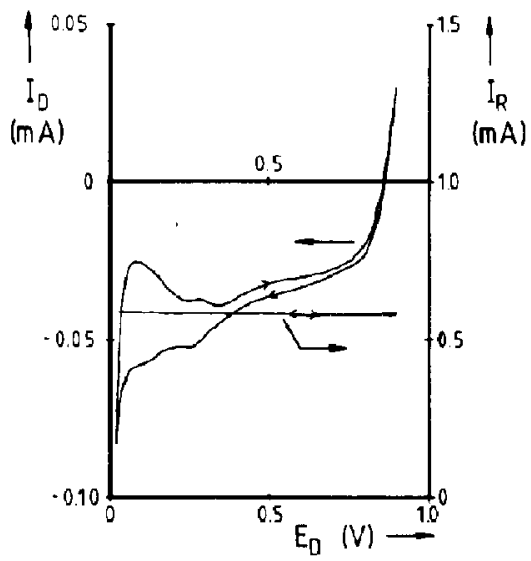

Fig. 5. Voltammogram for a reduced $\mathrm{PP}(\mathrm{Pt}) / \mathrm{Pt}$ rrde in $0.5 \mathrm{M} \mathrm{H}_{2} \mathrm{SO}_{4}+1.08 \times 10^{-3} \mathrm{M} \mathrm{H}_{2} \mathrm{O}_{2}$, deoxygenated with $\mathrm{N}_{2}$. Disc aged $67 \frac{1}{2} \mathrm{hr}$ at $E_{\mathrm{D}}=0.20 \mathrm{~V}$ in $\mathrm{O}_{2}$-saturated electrolyte. $v_{\mathrm{D}}=0.05 \mathrm{~V} \mathrm{~s}^{-1}, E_{\mathrm{R}}=1.25 \mathrm{~V}, f=25 \mathrm{~Hz}, T=293 \mathrm{~K}$, $Q=0.6 \mathrm{kC} \mathrm{m}^{-2}$.

wave appears clearly and the reduction current is about $0.05 \mathrm{~mA}$ at $E_{\mathrm{D}}=0.10 \mathrm{~V}$.

When using the Levich equation, it follows that the height of the reduction wave is only a factor 0.048 of the theoretical diffusion limited current for direct peroxide reduction.

It is found that the voltammogram of Fig. 5 is formed by superposition of the voltammogram of an uncovered $\mathrm{Pt}$ disc [5] and the reduction wave of oxygen on the $\mathrm{PP}(\mathrm{Pt})$ disc as shown in the following discussion.

Subsequent addition of $\mathrm{O}_{2}$ to the electrolyte resulted in a cathodic reduction current with a maximum value of about $0.710 \mathrm{~mA}$ at $E=0.10 \mathrm{~V}$. Using a corrected ring current at $E_{\mathrm{D}}=0.10 \mathrm{~V}$ of $0.143 \mathrm{~mA}$, it follows that $p\left(\mathrm{H}_{2} \mathrm{O}\right)=0.09$ and $I_{\mathrm{D}} / I_{\mathrm{D}, l}=0.52$. So, the diminished peroxide reduction wave in the sweep curve in deoxygenated solution is not caused by a decreased permeability of the polypyrrole layer for $\mathrm{H}_{2} \mathrm{O}_{2}$, because in that case, $p\left(\mathrm{H}_{2} \mathrm{O}\right)$ would be higher than 0.09 
for the experiment of oxygen reduction, carried out after measuring the curve in deoxygenated electrolyte.

In Fig. 5, the $I_{\mathrm{D}}-E_{\mathrm{D}}$ curve is rather steep at the potential where it intersects the $E$-axis, ie at $E_{\mathrm{D}}=0.87 \mathrm{~V}$. There are now two possibilities, viz. $1^{\circ}: \mathrm{a}$ reversible redox reaction occurs, where the cathodic and anodic reactions are each other's reverse and $2^{\circ}: \mathrm{a}$ reduction current is becoming overcompensated by an anodic wave and the cathodic and anodic reactions are not each other's reverse.

It is known, that the $\mathrm{H}_{2} \mathrm{O}_{2} / \mathrm{O}_{2}$ redox couple is rather reversible at $\mathrm{Pt}$ electrodes, with $E^{\circ}=0.682 \mathrm{~V}[6]$ and $i_{\alpha}=3.98 \times 10^{-1} \mathrm{Am}^{-2}$ in an aqueous $1 \mathrm{M} \mathrm{H}_{2} \mathrm{SO}_{4}+0.1 \mathrm{M} \mathrm{H}_{2} \mathrm{O}_{2}$ solution[7]. From the Nernst equation and using $\left[\mathrm{H}^{+}\right]=1 \mathrm{M},\left[\mathrm{H}_{2} \mathrm{O}_{2}\right]$ $=1.08 \times 10^{-3} \mathrm{M}, p\left(\mathrm{O}_{2}\right)=100 \mathrm{kPa}$ and $T=293 \mathrm{~K}$, it follows that the equilibrium potential for this redox couple is $0.770 \mathrm{~V}$. This equilibrium potential is $0.10 \mathrm{~V}$ more negative than the intersection potential of $0.87 \mathrm{~V}$. Morcover, since the electrolyte is deoxygenated, the equilibrium potential is shifted into even more negative direction for $p\left(\mathrm{O}_{2}\right) \ll 100 \mathrm{kPa}$.

Although $\mathrm{O}_{2}$ could be formed by chemical $\mathrm{H}_{2} \mathrm{O}_{2}$ decomposition, it is unlikely that its partial pressure becomes as high as $2.5 \times 10^{5} \mathrm{kPa}$, which is necessary to obtain an equilibrium potential of $0.87 \mathrm{~V}$.

This means, that the reduction wave in Fig. 5 is not a result of $\mathrm{O}_{2}$ reduction to peroxide, so that possibility $1^{\circ}$ is excluded. The reduction current mentioned in possibility $2^{\circ}$ can be a result of peroxide or oxygen reduction to water. The anodic reaction is the oxidation of $\mathrm{H}_{2} \mathrm{O}_{2}$ to $\mathrm{O}_{2}$.

In case of peroxide reduction to water, the cathodic and anodic waves would be of equal magnitude and compensate each other, resulting in a net current of zero. Since this does not apply to Fig. 5, the oxygen reduction to water is the final possibility. An extra support for this conclusion is given by the fact that the reduction wave in Fig. 5 starts at a potential which is about equal to the potential where $\mathrm{O}_{2}$ reduction starts in $\mathrm{O}_{2}$-saturated electrolyte (compare for example Figs 2 and 5). Although the electrolyte is deoxygenated under the experimental conditions of Fig. 5, slow chemical decomposition of $\mathrm{H}_{2} \mathrm{O}_{2}$ apparently gives $\mathrm{O}_{2}^{\text {ad }}$, which is subsequently reduced to water, according to $\mathrm{O}_{2}^{\text {ad }}+4 \mathrm{H}^{+}+4 e^{-} \rightarrow 2 \mathrm{H}_{2} \mathrm{O}$, at a rate, determined by the $\mathrm{H}_{2} \mathrm{O}_{2}$ decomposition reaction. The overall reaction equation of this consecutive reaction path is: $\mathrm{H}_{2} \mathrm{O}_{2}+2 \mathrm{H}^{+}+2 e^{-} \rightarrow 2 \mathrm{H}_{2} \mathrm{O}$, ie it is an indirect reduction of peroxide to water.

The amount of oxygen, formed by the peroxide decomposition reaction is: $m=\frac{1}{2} k_{4} c_{2}^{\sigma}$ (the peroxide decomposition is here assumed to be a first order reaction with reaction rate constant $k_{4}$ ) and, since all $\mathrm{O}_{2}$ is reduced to $\mathrm{H}_{2} \mathrm{O}: m=-I_{\mathrm{D}} / 4 A_{\mathrm{D}} F$. This gives: $k_{4}=-I_{\mathrm{D}} / 2 A_{\mathrm{D}} F c_{2}^{\sigma}$.

Using $I_{\mathrm{D}}=-5.0 \times 10^{-5} \mathrm{~A}, A_{\mathrm{D}}=5.05 \times 10^{-5} \mathrm{~m}^{2}$, $F=96,500 \mathrm{C} \mathrm{mol}^{-1}$ and $c_{2}^{\sigma}=c_{2}^{\mathrm{s}}=1.08 \mathrm{~mol} \mathrm{~m}^{-3}$, it follows that $k_{4}=4.75 \times 10^{-6} \mathrm{~m} \mathrm{~s}^{-1}$ for the reduced electrode of Fig. 5.

There is also a possibility in which $\mathrm{H}_{2} \mathrm{O}_{2}$ disproportionates to $\mathrm{O}^{2 \mathrm{~d}}+\mathrm{H}_{2} \mathrm{O}$ and with subsequent reduction of $O^{\text {ad }}$. However, peroxide decomposition by platinum black occurs without cleavage of the $\mathrm{O}-\mathrm{O}$ bond[8], thus making this reaction path unlikely. The above deduction leads to an oxygen reduction scheme which includes the following reaction[1]:

$$
\begin{array}{ll}
\mathrm{O}_{2}+4 \mathrm{H}^{+}+4 e^{-} \rightarrow 2 \mathrm{H}_{2} \mathrm{O} & \left(k_{1}\right), \\
\mathrm{O}_{2}+2 \mathrm{H}^{+}+2 e^{-} \rightarrow \mathrm{H}_{2} \mathrm{O}_{2} & \left(k_{2}\right), \\
\mathrm{H}_{2} \mathrm{O}_{2}+2 \mathrm{H}^{+}+2 e^{-} \rightarrow 2 \mathrm{H}_{2} \mathrm{O} & \left(k_{3}\right) .
\end{array}
$$

For the temperatures 308,323 and $338 \mathbf{K}$, the reaction rate constants $k_{1}, k_{2}$ and $k_{3}$ are calculated from the $r$ rde data as pointed out in [1]. The results are given in Fig. 6. From this figure it follows that all $k$ values increase with increasing temperature.

With respect to the oxygen diffusion coefficient in, respectively, bulk electrolyte $\left(S_{1}\right)$ and polymer film $(D\})$, it is found that the ratio $D \mathrm{f} / D$ is practically independent of the temperature (Table 1). The diffusion coefficients are determined as pointed out in[1].

When the polypyrrole layer thickness is varied by passing various amounts of charges during polymer formation, the potential sweep curves of Fig. 7 are obtained. In this figure, the formation charge $Q$ is varied from 0.3 up to $2.4 \mathrm{kC} \mathrm{m}^{-2}$. When a polypyrrole electrode formed with a formation charge of $5.1 \mathrm{kC} \mathrm{m}^{-2}$ is dried by free standing in ambient air, the polymer layer blisters from the surface spontaneously.

Figure 7 shows that, with increasing layer thickness,

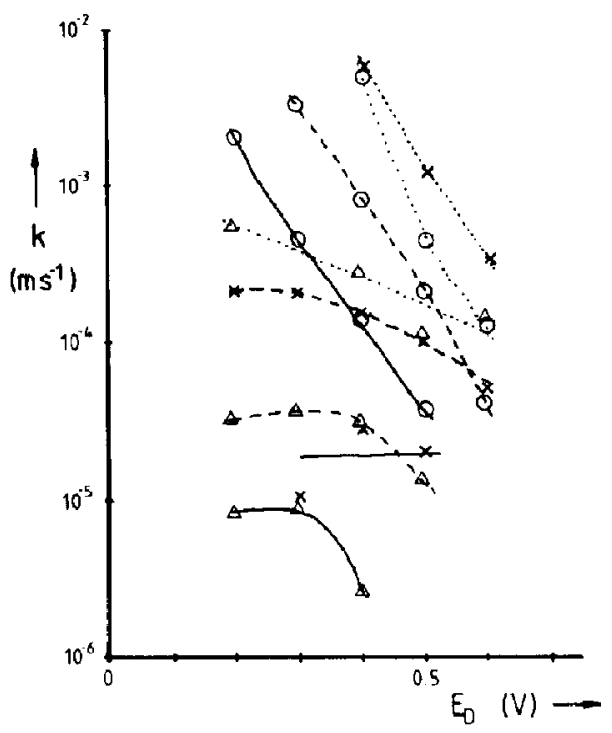

Fig. 6. $k_{1}(x), k_{2}(0)$ and $k_{3}(\Delta)$ as a function of $E_{\mathrm{D}}$ at various temperatures for a reduced $\mathrm{PP}(\mathrm{Pt}) / \mathrm{Pt}$ rrde in $\mathrm{O}_{2}$-saturated

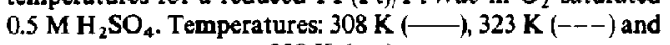
$338 \mathrm{~K}(\cdots)$.

Table 1. Oxygen diffusion coefficient in $0.5 \mathrm{M} \mathrm{H}_{2} \mathrm{SO}_{4}$ $(D \uparrow)$ and in polypyrrole $(D f)$ at various temperatures. Electrode aged for $72 \mathrm{hr}$ at $E_{\mathrm{D}}=0.20 \mathrm{~V}$ and $T=293 \mathrm{~K}$

\begin{tabular}{cccc}
\hline $\begin{array}{c}T \\
(\mathbf{K})\end{array}$ & $\begin{array}{c}D \$ \\
\left(10^{-9} \mathrm{~m}^{2} \mathrm{~s}^{-1}\right)\end{array}$ & $\begin{array}{c}D f \\
\left(10^{-11} \mathrm{~m}^{2} \mathrm{~s}^{-\mathbf{1}}\right)\end{array}$ & $\begin{array}{c}D_{[} / D_{\mathbf{1}} \\
\left(10^{-2}\right)\end{array}$ \\
\hline 308 & 3.7 & 5.1 & 1.4 \\
323 & 6.3 & 9.5 & 1.5 \\
338 & 9.0 & 13.0 & 1.5 \\
\hline
\end{tabular}




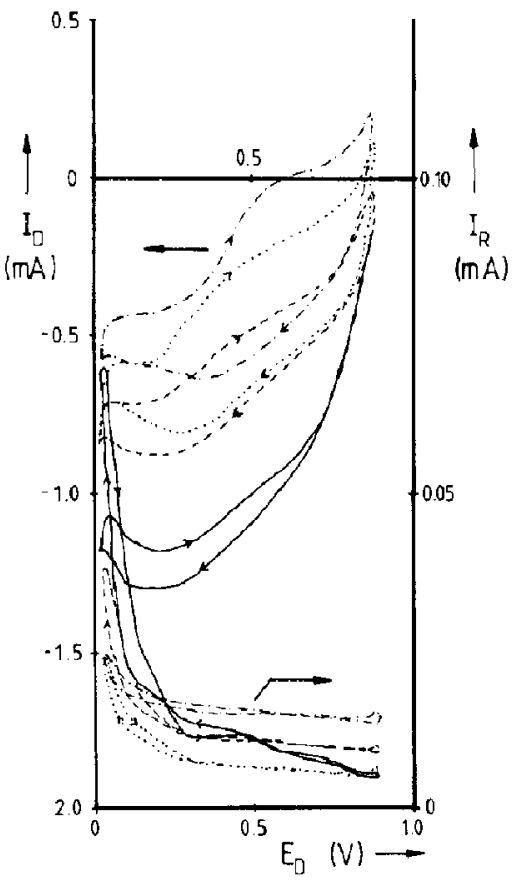

Fig. 7. Effect of polypyrrole layer thickness on $\mathrm{O}_{2}$ reduction at a reduced $\mathrm{PP}(\mathrm{Pt}) / \mathrm{Pt} r$ rde in $\mathrm{O}_{2}$-saturated $0.5 \mathrm{M} \mathrm{H}_{2} \mathrm{SO}_{4}$. Disc aged $2 \mathrm{hr}$ at $E_{\mathrm{D}}=0.20 \mathrm{~V}, v_{\mathrm{D}}=0.05 \mathrm{Vs}^{-1}, E_{\mathrm{R}}=1.25 \mathrm{~V}$, $f=25 \mathrm{~Hz}, \quad T=293 \mathrm{~K}$. Formation charges: $0.3 \mathrm{kCm}^{-2}$ (一), $0.6 \mathrm{kCm}^{-2}(--), 1.2 \mathrm{kCm}^{-2}(\cdots)$ and $2.4 \mathrm{kCm}^{-2}$ $(-\cdot-)$.

the oxygen reduction current and the net ring current $I_{\mathrm{R}}-I_{\mathrm{R}}^{0}$ decreases. Additionally, at higher values of $Q$, the polymer layer increasingly exhibits an electroactive behaviour, similar to the redox behaviour of polypyrrole films in acetonitrile[9]. An eventual change of the ohmic film resistance during the potential sweep of thicker polypyrrole films in $0.5 \mathrm{M} \mathrm{H}_{2} \mathrm{SO}_{4}$ could not be detected by $a c$-impedance measurements.

All the polypyrrole electrodes considered so far, were aged at a constant dise potential $\left(E_{\mathrm{D}}=0.20 \mathrm{~V}\right)$ and measured by triangular potential sweep.

When a PP(Pt) electrode is aged and measured by continuous triangular potential sweep between 0.02 and $0.85 \mathrm{~V}$, it appears that under these conditions, a pronounced decrease of the oxygen reduction current cannot be observed within a $21 \frac{1}{2}$ hr aging period. Besides a diminished aging effect, less bulk peroxide is formed when the electrode potential is continuously scanned. Moreover, there is less hysteresis between the anodic and cathodic sweep.

\subsection{Oxidized electrode}

The effect of an oxidized PP film $\left(Q=0.6 \mathrm{kC} \mathrm{m}^{-2}\right.$, aged at $E_{\mathrm{D}}=1.20 \mathrm{~V}$ ) on the oxygen reduction at a $\mathrm{Au} / \mathrm{Pt}(\mathrm{Au})$ rrde in $\mathrm{O}_{2}$-saturated $0.5 \mathrm{M} \mathrm{H}_{2} \mathrm{SO}_{4}$ is analogous to the effect found for a reduced PP film: the overpotential for oxygen reduction decreases when a polypyrrole film is applied. A cathodic peak in the disc sweep curve at $E_{\mathrm{D}} \simeq 1.2 \mathrm{~V}$ appears for both the $A u$ and the PP(Au) electrode, which corresponds to the reduction of gold oxides at the disc surface [10]. Figure 8 shows the water formation efficiency $p\left(\mathrm{H}_{2} \mathrm{O}\right)$ us $E_{\mathrm{D}}$, calculated from the data of the $\mathrm{Au} / \mathrm{Pt}(\mathrm{Au})$ and the $\mathbf{P P}(\mathbf{A u}) / \operatorname{Pt}(\mathbf{A u})$ electrode, respectively. Additionally, it has been found that $\left(I_{\mathrm{D}} / I_{\mathrm{D},}\right)_{\max }$ is about 1.0 for the uncovered $\mathrm{Au}$ electrode and about 0.4 for the $\mathrm{PP}(\mathrm{Au})$ electrode.

When using a Pt disc, the results in Fig. 9 are found for the uncovered and PP-covered disc respectively.

The figure shows that the oxygen reduction current is lowered by about a factor 2 when the PP electrode is used, whereas the ring current is lowered by more than a factor 10 .

The ring current curve, measured using the PP electrode, shows two peaks in the cathodic scan and one peak in the anodic scan.

For the water formation efficiency $p\left(\mathrm{H}_{2} \mathrm{O}\right)$ of the $\mathrm{Pt}$ and $\mathrm{PP}(\mathrm{Pt})$ electrode it appears that in the potential

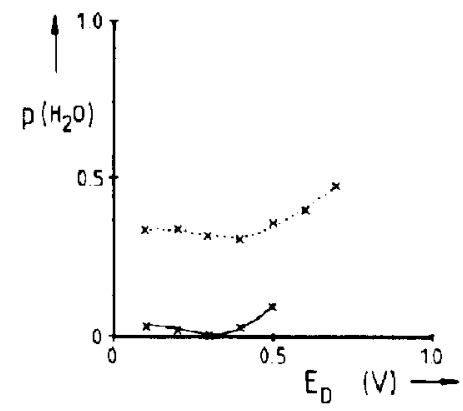

Fig. 8. Water formation efficiency during $\mathrm{O}_{2}$ reduction at an oxidized $\mathrm{Au} / \mathrm{Pt}(\mathrm{Au})$ rrde in $\mathrm{O}_{2}$-saturated $0.5 \mathrm{M} \mathrm{H}_{2} \mathrm{SO}_{4}$. Disc aged $1 \frac{1}{2} \mathrm{hr}$ at $E_{\mathrm{D}}=1.20 \mathrm{~V}$. $v_{\mathrm{D}}=0.05 \mathrm{Vs}^{-1}, f=25 \mathrm{~Hz}$, $T=293 \mathrm{~K}$. Uncovered disc. ---, PP-covered disc $\left(Q=0.6 \mathrm{kC} \mathrm{m}^{-2}\right)$.

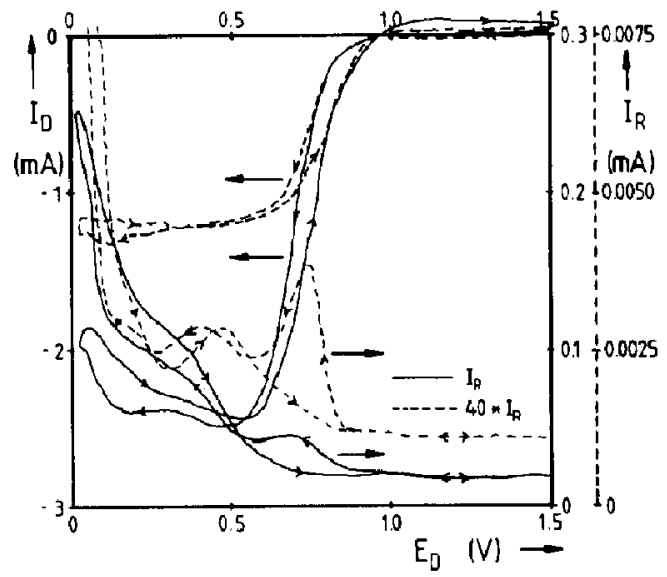

Fig. 9. $\mathrm{O}_{2}$ reduction at an oxidized $\mathrm{Pt} / \mathrm{Pt}$ rrde in $\mathrm{O}_{2}$ saturated $0.5 \mathrm{M} \mathrm{H}_{2} \mathrm{SO}_{4}$. Disc aged $\frac{1}{2} \mathrm{hr}$ at $E_{\mathrm{D}}=1.20 \mathrm{~V}$. $v_{\mathrm{D}}$ $=0.05 \mathrm{~V} \mathrm{~s}^{-1}, E_{\mathrm{R}}=1.25 \mathrm{~V}, f=25 \mathrm{~Hz}, T=293 \mathrm{~K}$. Uncovered disc. --- , PP-covered disc $\left(Q=0.6 \mathrm{kC} \mathrm{m}^{-2}\right)$; ring current enlarged 40 times. 
range $0.1 \mathrm{~V}<E_{\mathrm{D}}<0.6 \mathrm{~V}, \boldsymbol{p}\left(\mathrm{H}_{2} \mathrm{O}\right)$ is more than 0.98 for the PP electrode.

A plot of $I_{\mathrm{D}} / I_{\mathrm{D}, l}$ vs $E_{\mathrm{D}}$ for the PP electrode shows a plateau with $I_{\mathrm{D}} / I_{\mathrm{D}, l} \simeq 0.5$ for $0.1 \mathrm{~V}<E_{\mathrm{D}}<0.5 \mathrm{~V}$.

When the oxidized PP electrode was aged at a potential of $E_{\mathrm{D}}=1.20 \mathrm{~V}$, the rrde potential sweep curves did not change during an aging period of $24 \mathrm{hr}$.

For a PP electrode $\left(Q=0.6 \mathrm{kC} \mathrm{m}^{-2}\right)$ which was first aged for $2 \mathrm{hr}$ at $E_{\mathrm{D}}=0.20 \mathrm{~V}, p\left(\mathrm{H}_{2} \mathrm{O}\right)$ at $E_{\mathrm{D}}$ $=0.20 \mathrm{~V}$ recovered from about 0.92 to 0.98 after the electrode was subsequently aged for $2 \mathrm{hr}$ at $E_{\mathrm{D}}$ $=1.20 \mathrm{~V}$.

A potential sweep curve for an oxidized $\mathbf{P P}(\mathbf{P t}) / \mathbf{P t}$ electrode in peroxide-containing, deoxygenated electrolyte shows a disc current plateau for $E_{\mathrm{p}}<0.8 \mathrm{~V}$. The disc current at this plateau is about $0.6 \mathrm{~mA}$, which is about 0.46 times the diflusion limited peroxide reduction current at an uncovered electrode (calculated using the Levich equation). Since the factor 0.46 corresponds to the $I_{\mathrm{D}} / I_{\mathrm{D}}$, value for the PP electrode in $\mathrm{O}_{2}$-saturated electrolyte, it is likely that, for $E_{\mathrm{D}}<0.8 \mathrm{~V}$, the disc current is limited by peroxide diffusion through the PP film. Additionally, the sweep curve shows an anodic disc current plateau, of which the height equals the height of the cathodic plateau.

The explanation of the reduction wave in deoxygenated solution is identical to the one given for the indirect peroxide reduction at a reduced PP electrode, $i e$ the reduction wave is a result of oxygen reduction via $\mathrm{O}_{2}^{2 d}+4 \mathrm{H}^{+}+4 e^{-} \rightarrow 2 \mathrm{H}_{2} \mathrm{O}$, preceded by decomposition of peroxide according to $2 \mathrm{H}_{2} \mathrm{O}_{2} \rightarrow \mathrm{O}$ a्d $+2 \mathrm{H}_{2} \mathrm{O}$.

The peroxide decomposition reaction occurs with such a high rate constant, that limitation by peroxide diffusion takes place. This explains the equal magnitude of the cathodic and anodic wave.

Until so far, all the polypyrrole films were formed in a formation electrolyte to which no extra water was added. Water addition to the formation electrolyte, however, has an influence on the characteristics of the polypyrrole film $[3,9]$, so it will possibly also affect the oxygen reduction at PP electrodes.

The addition of various amounts of water to the formation electrolyte shows that the $\mathrm{O}_{2}$ reduction current at $E_{\mathrm{D}}<0.6 \mathrm{~V}$ increases with increasing water addition for additions of, respectively, $0.5,1.0$ and 5.0 vol. $\%$. Simultaneously with this increasing $\mathrm{O}_{2}$ reduction current, the net ring current $I_{\mathrm{R}}-I_{\mathrm{R}}^{0}$ increases with increasing water addition, except for $5 \mathrm{vol} \%$ $\mathrm{H}_{2} \mathrm{O}$.

When $p\left(\mathrm{H}_{2} \mathrm{O}\right)$ is calculated from these data and plotted against the disc potential, Fig. 10 is obtained. Figure 10 shows a decrease in water formation fraction for the water additions up to $1.0 \mathrm{vol} . \%$. A plot of $I_{\mathrm{D}} / I_{\mathrm{D}, l}$ os $E_{\mathrm{D}}$ shows an increase of $I_{\mathrm{D}} / I_{\mathrm{D}, l}$ with increasing water addition for all the water additions.

In particular this plot of $I_{\mathrm{D}} / I_{\mathrm{D}, l}$ supports the conclusion that water addition to the formation electrolyte increases the polymer film permeability (probably by increasing the porosity). An increase of permeability of the PP layer for reaction species should in our model result in a decrease of $p\left(\mathrm{H}_{2} \mathrm{O}\right)$ as will be shown in the discussion. The behaviour of the $p\left(\mathrm{H}_{2} \mathrm{O}\right)-E_{\mathrm{D}}$ curve in Fig. 10 is in accordance with this, except for the 5.0 vol. \% water addition.

Generally, it appeared that water addition to the formation electrolyte improved the adhesion of the

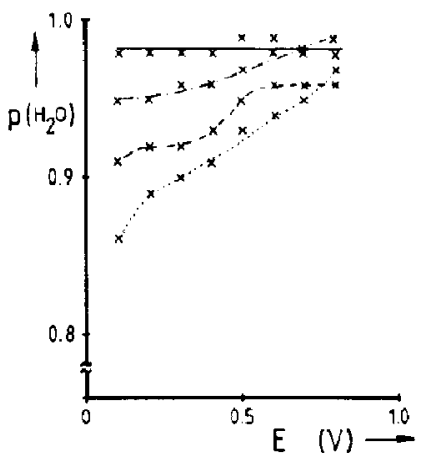

Fig. 10. Effect of water addition to the formation electrolyte on the water formation efficiency during $\mathrm{O}_{2}$ reduction at an oxidized $\mathrm{PP}(\mathrm{Pt}) / \mathrm{Pt}$ rrde in $\mathrm{O}_{2}$-saturated $0.5 \mathrm{M} \mathrm{H}_{2} \mathrm{SO}_{4}$. Disc aged $1 \frac{1}{2} \mathrm{hr}$ at $E_{\mathrm{D}}=1.20 \mathrm{~V}$. $v_{\mathrm{D}}=0.05 \mathrm{~V} \mathrm{~s}^{-1}, f=25 \mathrm{~Hz}, T$ $=293 \mathrm{~K}, Q=0.6 \mathrm{kC} \mathrm{m}^{-2}$. Water addition: no water added $(-), 0.5$ vol. $\%(---), 1.0$ vol. $\%(\cdots)$ and 5.0 vol. $\%$ $(-\cdot-\cdot)$.

oxidized polypyrrole layer to the $P$ t surface.

Potential sweep curves of oxidized PP electrodes with varying layer thickness have been measured. It has been found, that the effect of the layer thickness is similar to the one for the reduced PP electrode shown in Fig. 7, An increase of the formation charge gives an increase of $p\left(\mathrm{H}_{2} \mathrm{O}\right)$.

The results, obtained with a reduced and an oxidized poly- $N$-methylpyrrole (PMP) electrode, were similar to the results which were found for the PP electrode However, when the potential of a reduced PMP electrode was scanned between 0.02 and $0.85 \mathrm{~V}$ after aging at $E_{\mathrm{D}}=0.20 \mathrm{~V}$, the voltammogram recovered to that of an oxidized PMP electrode after one or two sweeps.

\section{DISCUSSION}

The results show that the cathodic reduction of dissolved oxygen at a polypyrrole electrode takes place at the interface metal/polypyrrole. The electrocatalytical nature of the metal substrate affects clearly the cathodic reduction of dissolved oxygen. The selectivity for the oxygen reduction to water depends upon the thickness (Fig. 7) and permeability of the polypyrrole film (Fig. 10), on the oxidation state of the electrode (reduced or oxidized) (Figs 3 and 9). The effect of the thickness and the permeability of the polymer layer on the selectivity becomes clear when the situation is regarded with virtually no peroxide in the bulk electrolyte, ie $c \S=0$. Equation (15) in[1] becomes then:

$$
\begin{aligned}
\frac{-I_{\mathrm{D}}}{I_{\mathrm{R}, 1}-I_{\mathrm{R}, 1}^{0}}= & \frac{1}{N}\left[\frac{2\left(k_{1}+k_{2}\right)}{k_{2}}\left(k_{3} \frac{l}{D \mathfrak{\zeta}}+1\right)\right. \\
& \left.+\frac{2\left(k_{1}+k_{2}\right)}{k_{2}} k_{3} \frac{\delta_{2}}{D_{2}^{s}}-1\right] .
\end{aligned}
$$

The above equation and Equation (29) in [1] show that, with increasing polymer thickness l or decreasing peroxide diffusion coefficient $D \frac{\zeta}{2},-I_{\mathrm{D}} /\left(I_{\mathrm{R}, l}-I_{\mathrm{R}, l}^{0}\right)$ and thus $p\left(\mathrm{H}_{2} \mathrm{O}\right)$ increases. 
It has been found for gold and platinum substrates, that the deposition of a polypyrrole layer on the metal substrate, gives indeed an oxygen electrode with an increased $p\left(\mathrm{H}_{2} \mathrm{O}\right)$ (Figs 1, 8 and 9).

It will be obvious that there is also an effect of the polymer layer thickness on the cathodic limiting disc current $I_{\mathrm{D} .1}$ (Fig. 7). Using $I_{\mathrm{D}, t}=-A_{\mathrm{D}} n_{\mathrm{a}} F D_{\mathrm{f}} c_{\mathrm{l}}^{\mathrm{s}} / \delta_{1}^{\prime}$ with Equation (10) in [3] and Equations (3), (4) and (5) in [1], it follows that

$$
\begin{aligned}
\frac{1}{I_{\mathrm{D}, I}}= & \frac{-1}{A_{\mathrm{D}} n_{\mathrm{a}} F c_{\mathrm{I}}} \\
& \times\left(\frac{2.8 \times 10^{-10} Q}{D_{1}^{\mathrm{f}}}+\frac{1.61\left(D_{\mathrm{s}}^{\mathrm{s}}\right)^{-2 / 3} v^{1 / 6}}{\sqrt{2 \pi f}}\right)
\end{aligned}
$$

in which $Q$ is the formation charge of the polypyrrole film. When $1 / I_{\mathrm{D}}$ at $E_{\mathrm{D}}=0.20 \mathrm{~V}$ and $f=25 \mathrm{~s}^{-1}$ is plotted against $Q$ for the data of the reduced (Fig. 7 and an experiment with $Q=5.1 \mathrm{kC}^{-2}$ ) and the oxidized electrode, Fig. 11 is obtained.

Substituting $A_{\mathrm{D}}=5.05 \times 10^{-5} \mathrm{~m}^{2}, \quad n_{\mathrm{a}}=4, \quad F$ $=96,500 \mathrm{C} \mathrm{mol}^{-1}, \quad c_{1}^{\mathrm{s}}=1.03 \mathrm{~mol} \mathrm{~m}^{-3}, \quad D_{\mathrm{f}}=2.1$ $\times 10^{-11} \mathrm{~m}^{2} \mathrm{~s}^{-1}, \quad D_{1}=2.1 \times 10^{-9} \mathrm{~m}^{2} \mathrm{~s}^{-1}, \quad v=1.07$ $\times 10^{-6} \mathrm{~m}^{2} \mathrm{~s}^{-1}[1]$ and $f=25 \mathrm{~s}^{-1}$ in Equation (2), gives a theoretical slope of $-0.67 \mathrm{~m}^{2} \mathrm{~A}^{-1} \mathrm{C}^{-1}$ and $a$

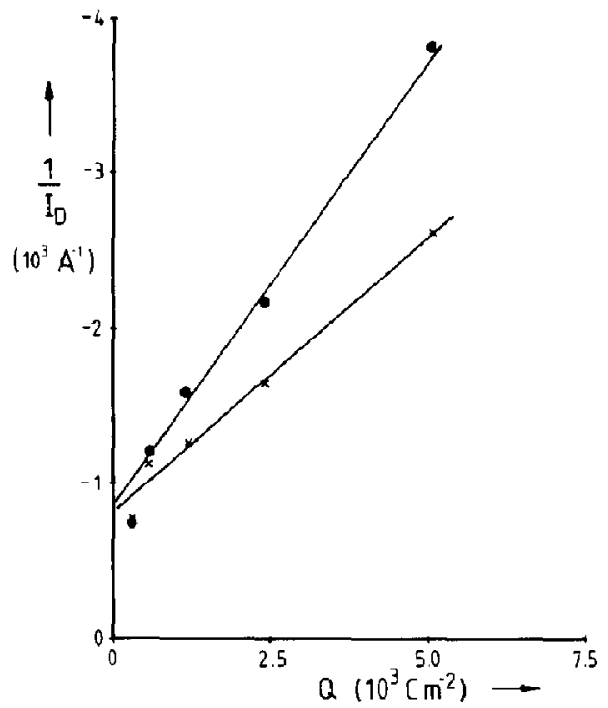

Fig. 11. Plot of $1 / I_{D}$ at $E_{D}=0.20 \mathrm{~V}$ us $Q$ for $\mathrm{O}_{2}$ reduction at a $\mathrm{PP}(\mathrm{Pt}) / \mathrm{Pt} r$ rde in $\mathrm{O}_{2}$-saturated $0.5 \mathrm{M} \mathrm{H}_{2} \mathrm{SO}_{4}$. $v_{\mathrm{D}}$ $=0.05 \mathrm{Vs}^{-1}, f=25 \mathrm{~Hz}, T=293 \mathrm{~K}$. (x) Reduced disc, aged $2 \mathrm{hr}$ at $E_{\mathrm{D}}=0.20 \mathrm{~V}$. Slope: $0.36 \mathrm{~m}^{2} \mathrm{~A}^{-1} \mathrm{C}^{-1}$. Intercept at $Q=0: 0.81 \times 10^{3} \mathrm{~A}^{-1}$. (C) Oxidized disc, aged $2 \mathrm{hr}$ at $E_{\mathrm{D}}=1.20 \mathrm{~V}$. Slope: $0.57 \mathrm{~m}^{2} \mathrm{~A}^{-1} \mathrm{C}^{-1}$. Intercept at $Q=0$ : $0.85 \times 10^{3} \mathrm{~A}^{-1}$. value for $1 / I_{\mathrm{D}}$ at $Q=0$ of $-0.39 \times 10^{3} \mathrm{~A}^{-1}$ for the plot of Fig. 11, which is in the same order of magnitude as the data in this figure. The substitution of $n_{\mathrm{a}}=4$ in Equation (2) is justified, since $p\left(\mathrm{H}_{2} \mathrm{O}\right)$ was more than 0.9 in the measurements from which Fig. 11 is obtained, so $3.8 \leqslant n_{\mathrm{a}} \leqslant 4.0$. The effect of the oxidation state of the polypyrrole electrode on the selectivity is illustrated by the fact that an oxidized $P P$ electrode exhibits a higher $p\left(\mathrm{H}_{2} \mathrm{O}\right)$ than a reduced $P P$ electrode (Figs 3 and 9). Moreover, the reduced electrode shows a pronounced aging effect, ie $p\left(\mathrm{H}_{2} \mathrm{O}\right)$ decreases with increasing aging time; the aging effect increases in rate with increasing temperature (Fig. 4). The model, in which the bulk peroxide is taken into account, has proved to be satisfactory for the reduced PP electrode.

It is concluded, that the reduction of hydrogen peroxide to water occurs in two steps for a PP electrode, viz. $1^{\circ}$ : decomposition via $2 \mathrm{H}_{2} \mathrm{O}_{2} \rightarrow \mathrm{O}_{2}^{\mathrm{d}}$ $+2 \mathrm{H}_{2} \mathrm{O}$, followed by $2^{\circ}$ : cathodic reduction of $\mathrm{O}_{2}^{\text {ad }}$ via $\mathrm{O}_{2}+4 \mathrm{H}^{+}+4 e^{-} \rightarrow 2 \mathrm{H}_{2} \mathrm{O}$. The difference in catalytical behaviour, especially with respect to the selectivity, between a reduced and an oxidized PP electrode may well be a consequence of the increased rate of the peroxide decomposition, which is found for the oxidized electrode. Besides this (electro-)catalytical effect, a decrease of the overpotential for oxygen reduction at an uncovered Au electrode is observed when the $\mathrm{Au}$ electrode is covered with a polypyrrole film (Fig. 1). This is in contrast with the statement of Okabayashi et al., who assign no electrocatalytical activity for any electrode reaction to $\mathrm{ClO}_{4}^{-}$-doped polypyrrole films[11].

\section{REFERENCES}

1. R. C. M. Jakobs, L. J. J. Janssen and E. Barendrecht, Electrochim. Acta 30, 1085 (1985).

2. R. C. M. Jakobs, Thesis, Eindhoven University of Technology, 31 (1984).

3. R. C. M. Jakobs, L. J. J. Janssen and E. Barendrecht, Recl. Trav. Chim. Pays-Bas 103, 275 (1984).

4. D. J. G. Ives and G. J. Janz, Reference Electrodes, p. 106. Academic Press, New York (1961).

5. Encyclopedia of Electrochemistry of the Elements (Edited by A. J. Bard), Vol. 9, Part A, p. 530. Marcel Dekker, Inc. New York (1982).

6. Encyclopedia of Electrochemistry of the Elements (Edited by A. J. Bard), Vol. 2, p. 193. Marcel Dekker, Inc., New York (1974).

7. J. P. Hoare, J. electrochem. Soc. 112, 608 (1965).

8. M. Anbar, J. Am. chem. Soc. 83, 2031 (1961).

9. A. Diaz, Chem. Scripta 17, 145 (1981).

10. Encyclopedia of Electrochemistry of the Elements (Edited by A. J. Bard), Vol. 4, p. 126. Marcel Dekker, Inc., New York (1975).

11. K. Okabayashi, O. Ikeda and H. Tamura, J. chem. soc, chem. Commun. 684 (1983) 